\title{
Understanding Dynamic Capabilities from Its Antecedents, Processes and Outcomes
}

\author{
Vilmar Antônio Gonçalves Tondolo ${ }^{\dagger}$ \\ Universidade de Caxias do Sul \\ Cláudia Cristina Bitencourt ${ }^{\Omega}$ \\ Universidade do Vale do Rio dos Sinos
}

\begin{abstract}
The theory of Dynamic Capabilities has been one of the references in the search for understanding of the competitive advantage of organizations. However, even with the development of studies on this topic, it is not clear how the Dynamic Capabilities develop and operate within organizations. Thus, this study aims to understand the dynamics capabilities from its antecedents, processes and outcomes. Through a literature review, it was possible to identify external and internal antecedents that make Dynamics Capabilities emerge in organizations, such as environmental dynamism and corporate entrepreneurship. In when it comes to process, it was identified that the Dynamic Capabilities are formed by a set of processes that have effect on resources and organizational capabilities. Thus, the development of resources and capabilities is the outcome of Dynamic Capabilities. Finally, unlike other studies, this work considers the DCs not as a specific capacity, but as a set of processes that enable the organization to deal with changes in the competitive environment.
\end{abstract}

Keywords: Dynamic capabilities. Antecedents. Processes. Outcomes.

* Author for correspondence:

${ }^{t}$. Doctorate in Administration from the University of Vale do Rio dos Sinos

Institution: Professor at the University of Caxias do Sul

Address: Rua Ernesto Alves, Caxias do Sul -

RS - Brazil - E-mail: vtondolo@gmail.com Telephone: (54) 30289671

\footnotetext{
${ }^{\Omega}$ Doctorate in Administration from the Federal University of Rio Grande do Sul Institution: Professor at the University of Vale do Rio dos Sinos

Address: Av. Inácio Vasconcelos, Porto Alegre - RS - Brazil - E-mail: claudiacb@unisinos.br Telephone: (51)35908186
} 


\section{INTRODUCTION}

he Dynamic Capabilities (DCs) have drawn attention of researchers in the of organizational strategy's field of study, especially regarding the development of resources and capabilities (TEECE; PISANO; SHUEN, 1997; AMBROSINI; BOWMAN, 2009; WANG; AHMED, 2007; BIAZZI, 2012). However criticism to the theory of DCs are found in the literature, based mainly on matters involving: terminology (ZAHRA; SAPIENZA; DAVIDSON, 2006); tautology (ZOLLO; WINTER, 2002) and research methods (DELBRIDGE; GRATTON; JOHNSON, 2006). Thus, even with the growth of studies on DCs (AMBROSINI; BOWMAN, 2009), there is still a great effort on the development of the theory, as well as a review of some concepts considering the practice of organizations (WANG; AHMED, 2007). As pointed out by Alsos et al. (2007), to clarify how the DCs operate in the development of organizational capabilities is a central point for the theoretical developed of DCs. In other words, there is a long way to go to establish a consensus about what are and how to develop DCs (ARGOTE; REN, 2012).

Another important point to note is the Resource Based View (RBV) and the DCs complementary or substitute (MAKADOK, 2001)? Even though the cited author answered this question, there is still certain skepticism pointed out in the literature. For example, the DCs as well as RBV, have a "negative legacy", that is, the inconsistencies that are criticized in the literature stem from the excessive fragmentation of the strategy's field of study itself (GREEN; LARSEN; KAO, 2008). As a complement, the large number of concepts and definitions, for example, what resources and capabilities are, help to generate ambiguity in both theories (WANG; AHMED, 2007; MENON, 2008; HELFAT; WINTER, 2011). Even so, the literature also highlights the value of RBVs and DCs in the quest for understanding the sources of competitive advantage (MENON, 2008).

The DCs' theory is also criticized for not having a complete answer regarding dynamization capacity (SCHREYÖGG; KLIESCH-EBERL, 2007). One possible answer is the excessive focus on post hoc solutions, instead of a search of answers based on the effect of DCs on the resources and organizational capacities. In addition, there are difficulties in segregating the outcomes of the DCs (ZAHRA; SAPIENZA; DAVIDSON, 2006), to differentiate them from the core competencies (WILKENS; MENZEL; PAWLOWSKY, 2004) and, not least, the difficulty of identifying the processes of DCs that operate within organizations (LAWSON; SAMSON, 2001). 
Based on these aspects, this paper presents the following main question: What are the antecedents, processes and outcomes of DCs? Thus, this study aims to identify these aspects, looking for somehow advance the discussions on DCs, contributing to future studies on this topic. Regarding the antecedents, it is considered essential to theoretical development to identify what aspect or aspects motivate the development of DCs in organizations. On the process, it is also considered important to identify the aspects that constitute the DCs. As well as in the outcomes, is sought to identify the contribution of DCs in organizations.

Thus, this study has as reference the following definition of DCs: "the organizations ability to integrate, build and reconfigure internal and external competencies to address rapidly changing environments" (TEECE; PISANO; SHUEN, 1997, p. 516.). This concept emphasizes the DCs as a set of processes that result in changes in the feature set and current capabilities of an organization in order to adapt the organization to cope with environmental changes.

Aiming to attain the goal, this study, characterized as a theoretical essay, was developed through literature review. Therefore, the approaches of Baumeister and Leary (1997) and Torraco (2005) were used. As pointed out by these authors, the literature review contributes to produce new knowledge about the topic, develop more integrative research questions and generate new frameworks and perspectives.

This study is organized into the following sections: first, is discussed the origin and relationship between the approach of Resources and Dynamic Capabilities. Further, the DCs are presented based on the discussion of the elements, as follows: approach, antecedents, processes and outcomes of Dynamic Capabilities. Finally, we present the conclusions and references.

\section{ORIGIN AND RELATIONSHIP BETWEEN THE APPROACH OF RESOURCES AND DYNAMIC CAPABILITIES}

The field of study of strategy began to be established in the $1970 \mathrm{~s}$, since then it has grown and gained the attention of researchers in the field of management. Studies conducted in this area can be understood by an evolutionary logic (HERRMANN, 2005). For Hoskinsson et al. (1999), studies in strategy have evolved based on the search of a more scientific way to establish this field of study. From this point of view, the choice of a study on the strategy depends on the object of research and the researcher's own perceptions. For this reason, there is no "Infallible way" a priori, everything depends on the characteristics of the study, their context. 
As part of this evolutionary development of studies in the area of strategy, in the 1990s, emerged a new approach that rescued the internal analysis of the organization, the Resource Based View (RBV). The RBV highlights the superior performance and competitive advantage based on the differences of the internal corporate environment. This approach still needs further clarification and a more precise definition of its terms. Even so, should be considered as a consistent approach in determining the competitive advantage of organizations (BARNEY, 2001). This approach can be identified as a new era in strategy's field of studies (HERRMANN, 2005).

The authors, on the RBV logic, see the organization as a set of tangible and intangible resources. The difference between organizations comes from experience based on the trajectory as well as the consolidated assets, skills and organizational culture. These assets and capabilities determine the efficiency of the outcomes and effectiveness of the organization (COLLIS; MONTGOMERY, 1995). In this view, the competitive advantage is consolidated from valuable resources that are unique and difficult to imitate (BARNEY, 1991; 2001). In other words, the resources must be valuable, rare, inimitable and non-substitutable (VRIN) as well as the essence of strategy in operating resources and capabilities of the organization to leverage the competitive advantage (GRANT, 1991).

Works of Wernerfelt, Rumelt and Barney jointly outlined the basic principles of the $\mathrm{RBV}$, suggesting that it is possible to develop a theory of sustainable superior performance, through the analysis of organizational resources (BARNEY; ARIKAN, 2005). For the authors, in search of an understanding of competitive advantage, there are two parallel ways, similar to RBV, as follows: (i) the accumulation and management of intangible assets, and (ii) the theories of competence and corporate diversification, including DCs. The main logical argument of the RBV is that the creation, maintenance and renewal of competitive advantage occur according to the characteristics and dynamics of internal resources of the organization. Therefore, the RBV is not an integrated approach being divided into two approaches, one more dynamic and other more static (FOSS 1997). In this logic, Makadok (2001) highlights two related approaches: the resource-picking and capability-building. According to the same author, these two approaches aim to understand how managers generate economic rents for their business.

The first approach is related to RBV, noting that organizations get superior performance through differentiated resources from its competitors. The second approach is linked to DCs, emphasizing that organizations get superior performance through the development of 
resources and capabilities (MAKADOK, 2001). The main question in this second approach is the relationship between the development of new resources and capabilities and organizational performance (SAPIENZA et al., 2006). The prospect of DCs emerged from the RBV's unclear answer of how organizations gain competitive advantage in a dynamic and changing context (LOPÉZ, 2005; WANG; AHMED, 2007; MENON, 2008; AMBRONISI; BOWMAN, 2009).

In other words, the prospect of DCs extends the argument of RBV introducing evolutionary arguments (FERDINAND et al., 2005; WANG; AHMED, 2007; OLIVER; HOLZINGER, 2008), addressing how the resources can be created and how the current stock of resources can be renewed in changing environments (VERITY, 2005; MENON, 2008; AMBROSINI; BOWMAN, 2009); as well as focusing on the organization's ability to reconfigure its own routines to respond to these changes (DOVING; GOODERHAM, 2008; GREEN; LARSEN; KAO, 2008). It also recognizes the role of environmental dynamism (EISENHARDT, MARTIN, 2000) and co-evolution of learning mechanisms (ZOLLO, WINTER, 2002).

Being responsible for modifying resources and capabilities and, consequently, affect organizational performance, the DCs are more than just an addition of RBV (ZOTT, 2003). In short, DCs consider two main complementary aspects regarding RBV: the change in the external environment and the key role of strategic management (TEECE, PISANO, 1994; TEECE, PISANO, SHUEN, 1997; CAVUSGIL, SEGGIE; TALAY, 2007; LILLIS; LANE, 2007). The prospect of the DCs also contrasts the perspective of Porter's Five Forces, for example. Thus, the analysis of the environment considers not only the industry in by itself, but as a total business ecosystem (TEECE, 2007). In fact, the DCs as an organizational process can be related to the logic of exploration/exploitation, where environmental requirements must be understood by the organization, and sets of resources and capabilities are then configured to handle these requirements.

The DCs theory emerged from the combination of theoretical approaches to exploration and internal and external development of specific capabilities of the organization (e.g. PENROSE, 1962; TEECE, 1982; WENERFELT, 1984) in response to changes in the business environment from development of specific skills and renew of the already existing (e.g. IANSITI; CLARK, 1995; HENDERSON, 1994) (TEECE, PISANO, 1994). Studies emphasizing new types of organizational capabilities offered also significant contributions for the emergence of DCs, for example, Leonard-Barton (1992) and Collis (1994). Thus, the 
theory of the DCs have emerged already recognizing the role of exploration on the existing set of resources and organizational capabilities and the role of exploring new (combination, integration, renewal).

In other words, the prospect of DCs based on the evolutionary Schumpeterian view of competition between organizations. For this reason, the differences between organizations are generated by new combinations of resources and capabilities, developed by organizations throughout their existence (TEECE, PISANO, SHUEN, 1997). Indeed, the prospect of DCs complements the arguments of Schumpeter, emphasizing the role of the internal processes of the organization on the creation of new capabilities and combinations of resources, which are essential for competition. Moreover, the organizational processes are shaped and constrained by organizational trajectory itself (TEECE, PISANO, 1994). Complementing, the prospect of DCs is differentiated from other competitive advantage approaches (e.g., the five competitive forces, RBV, the strategic conflict approach) due to its potential to address the role of management in achieving competitive advantage in intense changing environments (TEECE, PISANO, SHUEN, 1997).

As it is shown, it is not enough for an organization to accumulate resources. The DCs emphasize two main aspects of the development of new forms of competitive advantage: the dynamics and capacity. The term "dynamics" refers to the character of change of the environment, requiring strategic responses (e.g., renewing skills), and the term "capacity" refers to the role of strategic management in dealing with requirements changes on the environment through internal organizational adaptation (e.g., adaptation, integration, and reconfiguration of organizational skills, resources and internal and external capabilities) (TEECE, PISANO, SHUEN, 1997; TEECE, PISANO, 1994). For this reason, the main argument involving the DCs is the potential of the organization to develop high-level capabilities through its trajectory, leveraging and/or sustaining superior performance (HELFAT, PETERAF, 2003; MARCUS, ANDERSON, 2006; HARRELD; O'REILLY III; TUSHMAN, 2007), rather than just have different features.

The discussion on DCs is based on evolutionary economics of Nelson and Winter, following the legacy of Alchian and Simon and March, which suggests that decisions under uncertainty are satisfactory rather than optimal due to the influence of bounded rationality (ZAHRA; SAPIENZA; DAVIDSSON, 2006). Capabilities are developed over time, but also the capabilities are caused by a sequence of decisions, generating a strategic commitment (GHEMAWAT, 2000). This strategic commitment can be seen as a path dependent element. 
In this sense, the heterogeneous resources and capabilities are developed throughout the history of the organization, through previous decisions and commitments (ALVAREZ, BARNEY, 2006). Choices made by organizations, in terms of development and/or combination of resources and capabilities, are the core of organizational strategy. The continuum of decisions and development of resources and capabilities is unique to each organization, making the resources and capabilities developed in this process difficult to imitate by competitors. Thus, the capabilities are dynamic skills, continuous learning and development and gathering of skills developed by organizations, differentiating them from their competitors (TEECE, PISANO, SHUEN, 1997). Dynamic capability, on the other hand, is the organization's ability to build, integrate, or reconfigure operational capabilities, not directly, resulting in increased profitability, but also significantly affecting the performance of the operational capacity of the organization (HELFAT, PETERAF, 2003).

On the DCs' approach, the development of resources and capabilities is internal to the organization. Accordingly, Eisenhardt and Martin (2000) emphasize that internal processes are the sources of DCs. The trajectory of the organization leads to the build up of knowledge capable of generating new routines ${ }^{\mathrm{i}}$ and processes over time (SAPIENZA et al., 2006). The DCs also highlight other internal organizational processes such as learning and innovation (MCGUINNESS; MORGAN, 2000).

Pisano (2000) associates the DCs to a particular type of routine, the dynamic routine. Thus standard procedures, continuous improvement and learning are examples of internal sources of DCs (GHEMAWAT, 2000). For more than two decades of research, the main point of the DCs is the ability to replicate and enhance the organizational capabilities (GAVETI, 2005). Knowledge is transferred among members of the organization through routines. This process allows the organization to develop new capabilities in order to achieve higher competitive level (SAPIENZA et al., 2006).

Moreover, it is central to understand the logic that permeates the DCs. Accordingly, based on Wang and Ahmed (2007), it is possible to establish a baseline of understanding. In other words, this development movement of DCs is based on a logic that starts in resources, culminating in DCs. Thus, the resources are the basis of all development. Capabilities represent the organization's ability to provide resources to achieve a specific goal. Core competencies refer to sets of resources and capabilities, which have central contribution to competitive advantage in a given period of time. And finally, the DCs represent the ongoing management of the resources, capabilities and core competencies, such as renovation, mainly 
to cope with changes in the environment and sustain competitive advantage over time (Wang; Ahmed, 2007). Therefore, operational capacities, or just capabilities, enable the organization to perform current activities. Above all, the DCs involve change, which involves resources, capabilities and even business models (HELFAT et al., 2007).

\section{APPROACHES OF DYNAMIC CAPABILITIES}

As discussed above, the DCs can be considered as a "dynamic" view of strategic approach to resources. This perspective has been studied since the work of Teece and Pisano (1994) and later in the work of Teece, Pisano and Shuen (1997) (CAVUSGIL; SEGGIE; TALAY, 2007). These authors define DCs as "the organization's ability to integrate, build and reconfigure internal and external competencies to address rapidly changing environments" (TEECE; PISANO; SHUEN, 1997, p. 516.). Their work can be considered as the most influential study on the DCs (SCHREYOGG; KLIESCH-EBERL, 2007; WITCHER; CHAU; HARDING, 2008).

According to Zollo and Winter (2002), an organization is viewed as a set of operational and administrative routines that evolve over time through performance feedback. Furthermore, the authors argue that the first definition opens up some questions, such as: what are the DCs and how do they operate? Based on different perspectives on DCs, this paper presents various definitions and notes its emphasis on each of them, as can be seen in Appendix A.

Literature provides several concepts of DCs. Analyzing each of them it is possible point out the following aspects: First, the DCs main outcome is to create, renew or integrate resources, assets, capabilities, skills and routines enabling organizations to monitor environmental changes. As Wang and Ahmed (2007, p. 40) argue "capacity development as an outcome of dynamic capabilities over time is often discussed and evidenced in empirical research."

Secondly, different aspects of DCs are emphasized as follows: Behavioural orientation; high-level management activities; organizational skills; organizational capabilities; organizational routines and processes; learning processes; organizational activities and standards. So it is not impossible to argue that the DCs are based on only one or a few aspects of an organization. In other words, DCs are seen as a set of organizational aspects which, over time, allow organizations to manage new external and internal competitive requirements. 
In this logic, recently, different approaches on the DCs have been highlighted in the strategy literature. Schreyögg and Kliesch-Eberl (2007) show three approaches on DCs, as follow: (i) radical dynamization approach; (ii) integrative approach; (iii) innovative routine approach. According to the authors, the radical dynamization approach consists in adapting the concept of capacity to the dynamic environment. In view of Enseinhardt and Martin (2000), the DCs are considered different from regular capabilities. In this sense, the DCs are able to adapt organizations to environmental changes through processes such as reconfiguration, integration and acquisition of resources. In other words, DCs develop a new set of capabilities, enabling organizations to monitor environmental changes. Concepts such as "adhocracy" and "organizational learning" are very close to this approach of DCs (SCHREYÖGG; KLIESCH-EBERL, 2007).

Based on ideas of Teece, Pisano and Shuen (1997), integrative approach is the most usual approach of DCs. DCs are seen as mechanisms to develop new skills demanded by environmental changes. Three dimensions (positions, paths and processes) enable the organization to adapt, integrate and reconfigure its set or stock of resources and capabilities. In addition to these three dimensions, DCs have learning and reconfiguration as subdimensions. This approach emphasizes the integration of static and dynamic elements (SCHREYÖGG; KLIESCH-EBERL, 2007), as example the integration of resources and capabilities.

Based on ideas of Nelson and Winter (1982) and Zollo and Winter (2002), the approach of innovation routine emphasizes the role of innovative routines on development and capabilities change. DCs in the form of innovative routine emerge from learning processes (SCHREYÖGG; KLIESCH-EBERL, 2007). Thus, in this view, DCs have three distinct approaches, each based on specific arguments.

Complementarily, Alsos et al. (2007), highlights two approaches for DCs. According to the authors, the first approach considers the DCs as an evolutionary process in which there are three stages, search (variation), selection (evaluation) and routinization (execution). This approach matches the approach of routine innovation highlighted by Schreyögg and KlieschEberl (2007).

The second approach considers the DCs as organizational mechanisms and processes, enabling organizations to build, reconfigure, integrate, rearrange and delete resources and capabilities in order to monitor the changes of the competitive requirements. Key processes of that vision are coordination, integration and learning (ALSOS et al., 2007). This approach 
corresponds to the radical dynamization and integrative approach outlined by Schreyögg and Kliesch-Eberl (2007). Thus, instead of three approaches to DCs, Alsos et al. (2007) supports two, represented by: routine, innovation, integration and learning aspects. Therefore, the DCs cannot be seen only as a capacity, but instead as a set of capabilities that are imbricated in organizational processes. Further in the text, it will be returned the discussion on imbricated processes in the DCs.

\section{ANTECEDENTS TO DYNAMIC CAPABILITIES}

In the quest for a broad understanding of DCs, it is necessary to identify and understand the issues prior to the dynamic capabilities, that is, the aspects that induce organizations to develop DCs. Through analysis of previous studies, two types of antecedents (external and internal) were identified for organizations. Requirements of the changing environment (TEECE; PISANO, 1994; TEECE; PISANO; SHUEN, 1997; RINDOVA; KOTHA, 2001; ADNER; HELTAF, 2003; BLYLER; COFF, 2003; TEECE, 2007) and market dynamism (EISENHARDT; MARTIN, 2000; WANG; AHMED, 2007) suggest that organizations facing dynamic environments and markets are more susceptible to DCs development. Moreover, stimulation and external feedback (ZOLLO; WINTER, 2002) complement the role of the external environment as an antecedent to DCs. For example, Drnevich and Kriauciunas (2011) and Molina; Bustinza and Gutiérrez-Gutiérrez (2012) identified through surveys that the dynamic environment positively affects DCs' development in organizations.

Moreover, they could also identify in the literature the importance of the internal environment. For example, the recognition, on the part of managers, of a need or opportunity to be exploited (MONTEALEGRE, 2002), internal groups interested in developing a capability (HELFAT; PETERAF, 2003) and entrepreneurial management (TEECE, 2007) highlight that organizations should be aware of what is happening, recognizing incentives and opportunities to be explored. In other words, opportunities should be identified and exploited (ZHARA; SAPIENZA; DAVIDSON, 2006), for an organization to develop DCs. Therefore it is highlighted the role of corporate entrepreneurship (ZHARA; SAPIENZA; DAVIDSON, 2006; TEECE, 2007). Thus, it can be assumed that the DCs' development is driven by external and internal antecedents (e.g., WANG, AHMED, 2007).

Keeping this logic, the idea behind the external and internal antecedents is to understand the DCs as a whole. Thus, they are required to continually adapt the organization in order to meet the demands of the changing environment and customers, shaping the market through the development of new products, processes and business models. The central logic is that the 
regular activities (e.g., incentive systems, costs control) are necessary but insufficient to maintain competitive advantage. Thus, the organization's performance still depends on additional actions, such as the discovery and development opportunities (prospecting and exploration), and many other related high-level capabilities, in which DCs are included (TEECE, 2007).

\section{PROCESSES OF DYNAMIC CAPABILITIES}

As previously observed, DCs are connected to various organizational aspects (processes, for example). According to this view, the DCs can be viewed as a process of higher order, which are made from a set of sub-processes (MENON, 2008; AMBROSINI; BOWMAN, 2009) and contained in such processes (WANG; AHMED, 2007). As pointed out by Teece, Pisano and SCHUEN (1997), organizational processes are considered a category of DCs. To these authors, "as managerial and organizational processes, we refer to how things are done in the organization, or what could be referred to as its routines, or patterns of current practice and learning "(p. 518). This feature opens an important debate about which are the DCs' processes, which are discussed below.

Based on Teece, Pisano and Schuen (2007), Ambronisi and Bowman (2009) emphasize that the reconfiguration, leverage, learning and creative integration are the main processes that comprise the DCs. Reconfiguration refers to the "transformation and the recombination of assets and resources, for example, the consolidation of the central support functions, which often occurs as an outcome of acquisition "(AMBRONISI; BOWMAN, 2009, p. 35). In this logic, the reconfiguration can be understood as a change in how the resources and organizational capabilities interact with themselves (MENON, 2008), resulting in internal restructuring (ALSOS et al., 2007). In other words, the reconfiguration underscores the role of management in conducting organizational and strategic change (HODGKINSON; HEALEY, 2011). Other authors also support the reconfiguration as DCs' process, including (WANG; AHMED, 2007; HELFAT; PETERAF, 2003; BLYLER; COFF, 2003; EISENHARDT; MARTIN, 2000; TEECE; PISANO, SCHUEN, 1997).

Leverage involves "replication of a process or system that is operating at a respective business unit in another different or expanding the resource's value using it in a new domain, for example, applying an existing brand into new set of products "(AMBRONISI; BOWMAN 2009, p. 35). As a result, a resource and/or capability is not built or refurbished, but it is replicated in another business context, or even partially replicated (HELTAF; PETERAF, 
2003). This process is central to competitive advantage (CAVUSGIL, SEGGIE; TALAY, 2007; TEECE, PISANO; SCHUEN, 1997; ALSOS et al., 2007.).

Learning "allows tasks to be done more effectively and efficiently as a result of experimentation and reflection on failure and/or success" (AMBRONISI; BOWMAN 2009, p. 35). In this context, learning generates new knowledge, new way of thinking, reflecting the use of organizational resources and capabilities (MENON, 2008); that is, allowing organization's activities to be performed faster (CAVUSGIL; SEGGIE; TALAY, 2007; TEECE; PISANO; SCHUEN, 1997). As pointed out by Zollo and Winter (2000), DCs emerge from learning mechanisms, being shaped by the evolution of learning over time. Thus, learning is the dynamic concept behind the DCs (CHEN; LEE, 2009; TEECE; PISANO; SCHUEN, 1997).

The creative integration "refers to the ability of the organization to integrate their assets and resources, resulting in a new configuration of resources" (AMBRONISI; BOWMAN 2009 , p. 35). The creative integration also refers to the ability of the organization to coordinate its set of features and capabilities, being of main importance to the process of use and reconfiguration (MENON, 2008; WANG; AHMED, 2007; CAVUSGIL; SEGGIE; TALAY, 2007; BLYLER; COFF, 2003; HELFAT; PETERAF, 2003; $\quad$ EISENHARDT; MARTIN, 2000; TEECE; PISANO, SCHUEN, 1997). It is worth noting that creative integration, besides reconfiguring the set of organizational resources and capabilities, it also refers to the integration of new features and capabilities to the existing set (ALSOS et al., 2007).

The perspective of the external environment cannot be ignored in the processes of DCs. For example, the observation and evaluation of the external environment, in order to monitor the environment, generating discovery of new opportunities and ideas (ALSOS et al., 2007). Thus, there is the process of sensing, which can be understood as the "organization's ability to accurately detect changes in its competitive environment, including potential changes in technology, competition, customers and regulation" (HARRELD; O'REILLY III; TUSHMAN, 2007, p. 24). That is, sensing refers to the identification of an opportunity (TEECE, 2012), referring to the logic of corporate entrepreneurship (HODGKINSON; HEALEY, 2011).

Once an opportunity is detected, the organization can turn it into products and/or services, logically following all paths, referring to the logic of seizing (TEECE, 2007). The seizing resumes the internal perspective of the organization, which can be understood as the 
"organization's ability to act on these opportunities and threats, to be able to take advantage of them, reconfiguring the tangible and intangible assets to meet new challenges" (HARRELD; O'REILLY III; TUSHMAN, 2007, p. 25). That is, the set of resources and capabilities must be mobilized to exploit the identified opportunity (TEECE, 2012). These two cases bring the logic of exploration/exploitation (TEECE, 2007), emphasizing the role of strategic transformation in organizations (HODGKINSON; HEALEY, 2011).

It is also noteworthy two additional processes, the acquisition of resources and capabilities and the elimination of resources. The acquisition takes the outside perspective, referring to the logic of acquisition, as well as access via inter-organizational relationships (ALSOS et al., 2007; EISENHARDT; MARTIN, 2000) and bonds formed by organizational capital (BLYLER; COFF, 2003). The elimination of resources and capacity refers to the selection process, that is, release the organization to make compromises with features and capabilities that are needed more than others, making the process of the renewal of the set and its features more agile, or at least possible (BLYLER; COFF, 2003; HELFAT; PETERAF, 2003; EISENHARDT; MARTIN, 2000). This process is similar to the selection process, highlighted by Zott (2003, p. 105), namely: selection refers to "organizational activities involved in identifying a preferred alternative for organizational change, such as the evaluation of alternatives."

As it is possible to identify in the literature, DCs are composed of specific processes (for example, leverage and learning). It is also possible to highlight at least two of the elements related to the emphases of DCs; an emphasis stresses learning and processes (for example, AMBROSINI; BOWMAN, 2009; TEECE, 2007; WANG; AHMED, 2007; EISENHARDT; MARTIN, 2000;. TEECE; PISANO; SHUEN, 1997). This emphasis has considerable influence from the work of Teece, Pisano and Shuen (1997). The other emphasis points the routines and learning mechanisms (for example, CHEN; LEE, 2009; ZOTT, 2003; ZOLLO; WINTER, 2002). This emphasis is influenced by the work of Nelson and Winter (1982). Finally, the ability of the life cycle (HELFAT; PETERAF, 2003) also emphasizes learning processes and routines, although with more emphasis on the trajectory from a development/maturation perspective.

Considering this, DCs may emerge in different ways. Some are necessary to integrate resources and capabilities, to reconfigure resources and capabilities, others are about the creation of new features and capabilities, while others are about disposal of resources and capabilities (AMBROSINI; BOWMAN, 2009). 


\section{OUTCOMES OF DYNAMIC CAPABILITIES}

Some criticism can be found in the literature regarding the outcomes of the DCs. In particular, the main question is whether or not the organizational performance is directly affected by the DCs (WANG; AHMED, 2007; AMBROSINI; BOWMAN, 2009). Based on literature review, this study agrees with the authors that argue that organizational performance is indirectly affected by DCs. Thus, it is argued that the DCs' first order outcome is the effect in the set of resources and organizational capabilities; In other words, it refers to the development of competence of a particular strategy. So the DCs' second-order outcome is double, being composed of adaptability to cope with changes in environmental requirements and therefore the organizations' performance.

Likewise, the literature is vast to submit DC's indicators. Thus, it is important to aggregate them into distinct categories. First, the DCs have effect on routines, resources, assets and organizational capabilities (TEECE; PISANO, 1994; TEECE; PISANO; SHUEN, 1997; EISENHARDT; MARTIN, 2000; ZOLLO; WINTER, 2002; MONTEALEGRE, 2002; ADNER; HELFAT, 2003; ZOTT, 2003; BLYLER; COFF, 2003; HELFAT; PETERAF, 2003; BOWMAN; AMBROSINI, 2003; ZHARA; SAPIENZA; DAVIDSON, 2006; TEECE, 2007; WANG; AHMED, 2007; AMBROSINI AND BOWMAN, 2009; HELFAT; WINTER, 2011; HSU; WANG, 2012). As an example we present the renewal of routines and capabilities, development of capabilities and high performance routines, the settings of new resources, adaptation and development of organizational routines and remodelling of the resource's base and organizational capabilities.

Second, to deal with environmental changes and the dynamics of the market are also outcomes of the DCs (TEECE; PISANO, 1994; TEECE; PISANO; SHUEN, 1997; EISENHARDT; MARTIN, 2000; RINDOVA; KOTHA, 2001, ZOLLO; WINTER, 2002; MONTEALEGRE, 2002; BLYLER; COFF, 2003; BOWMAN; AMBROSINI, 2003; ZHARA; SAPIENZA; DAVIDSON, 2006; TEECE, 2007; WANG; AHMED, 2007; AMBROSINI; BOWMAN, 2009; HELFAT; WINTER, 2011; HSU; WANG, 2012). Noteworthy are the continuous internal adjustment; adjust to the requirements of the environment; exploitation of resources and organizational capabilities; combining or creating market changes; new strategies; strategic flexibility; effectiveness and exploration of a need or opportunity. On this logic, Molinas Bustinza and Gutiérrez-Gutiérrez (2012) considered the strategic, structural and operational flexibility as a measure of DCs. 
Third, the competitive position and competitive advantage are final outcomes of the DCs (TEECE; PISANO, 2004; TEECE; PISANO; SHUEN, 1997; EISENHARDT; MARTIN, 2000; RINDOVA; KOTHA, 2001; ADNER; HELFAT, 2003; ZOTT, 2003; BLYLER; COFF, 2003; HELFAT; PETERAF, 2003; BOWMAN; AMBROSINI, 2003; ZHARA; SAPIENZA; DAVIDSON, 2006; TEECE, 2007; WANG; AHMED, 2007; AMBROSINI; BOWMAN, 2009). Thus, it can be considered that the DCs operate primarily in the set of resources and organizational capabilities. After that, organizations become adept at dealing with environmental/market requirements. As a final outcome, organizations improve their competitive position and its competitiveness. The outcomes found by Drnevich and Kriauciunas (2011) corroborate this perception. Through a survey, the authors found that the DCs did not significantly affect the performance level of firms, but rather affect, significantly, in terms of organizational processes, suggesting that the DCs do not automatically affect performance, however contribute appreciably to the competitiveness conditions of organizations.

\section{CONCLUSION}

This theoretical study aimed to identify antecedents, processes and outcomes of DCs. Unlike other studies, this work considers the DCs not as a specific capacity, such capacity for innovation, but as a set of processes that enable the organization to deal with changes in the competitive environment. As it still is a developing theory, studies that aim to broadly understand the theory are welcome. Therefore, this study is useful in that it can assist both qualitative and quantitative future empirical studies. For example, qualitative studies may use this work to define categories of analysis as quantitative studies can use aspect observed here and launch testable hypotheses.

Empirical studies on the DCs are still little explored (MENON, 2008), they focused on specific DCs (AMBROSINI; BOWMAN, 2009), showing disconnected results, prompting more research efforts towards an integrated understanding of DCs (WANG; AHMED, 2007). As noted by Teece (2012), studies on the logic of DCs are still recent. Thus, they offer challenges and opportunities for research. New studies on the resources and capabilities must go beyond the possession and use of value routines. Further studies could focus on the relationship of superior performance and the role of resource management, the importance of the organizational environment, the role of the consumer, the relation of the DCs with other theories (DOUGLAS; RYMAN, 2003; HOOPES; MADSEN; WALKER, 2003; WINTER, 2003; HELFAT; PETERAF, 2003; GAVETI, 2005; HERRMANN, 2005; SIRMON; HITT; 
IRELAND, 2007; PRIEM, 2007); manufacturing strategy (SCHROEDER; JUNTILA; BATES, 2002); internationalization (SAPIENZA et al., 2006.); managerial decisions (ADNER; HELFAT, 2003; ZAHRA; SAPIENZA; DAVIDSON, 2006; HODGKINSON; HEALEY, 2011); corporate social responsibility (MARCUS, ANDERSON, 2006), and antecedents, processes and outcomes (ZAHRA; SAPIENZA; DAVIDSON, 2006).

Some criticisms are found in the literature on DCs. For example the criticism on the terminology (ZAHRA; SAPIENZA; DAVIDSON, 2006; HELFAT, WINTER, 2011), tautology (ZOLLO; WINTER, 2002), as well as many different methods research resulting in many different meanings (DELBRIDGE, GRATTON \& JOHNSON, 2006), besides the difficulty of distinguishing between the various concepts of capabilities, such as the difference being dynamic and operational capabilities (HELFAT; WINTER, 2011). As noted in this study, there are at least three different approaches to the concept of DCs, corroborating the criticism. However this fact should be considered as a research opportunity, posing new studies aimed at fully understanding the concept of DCs.

Regarding the processes, the literature offers numerous examples. Somehow, this aspect is the tautological feature mentioned in this work. In order to be more understandable, this study categorized these processes as follows. First, there are elements pointing managerial and organizational processes, including learning mechanisms (TEECE; PISANO, 1994; TEECE; PISANO; SHUEN, 1997; EISENHARDT; MARTIN, 2000; ZOLLO; WINTER, 2002, ADNER; HELFAT, 2003; BOWMAN; AMBROSINI, 2003; ZOTT, 2003; ZHARA; SAPIENZA; DAVIDSON, 2006; TEECE, 2007; AMBROSINI; BOWMAN, 2009), such as coordination/integration, learning and reconfiguration. These elements focus on changing routines, resources and capabilities.

Secondly, there are processes that highlight positions of organizations (TEECE; PISANO, 2004; TEECE; PISANO; SHUEN, 1997; HELFAT; PETERAF 2003; ZOTT, 2003), representing the commitment to the development of tangible and intangible assets. Third, there are processes with a focus on path dependency (TEECE; PISANO, 1994; TEECE; PISANO, SHUEN, 1997). Fourth, managerial and individual aspects (ADNER; HELFAT, 2003; BLYLER; COFF, 2003; HSU; WANG, 2012) are also elements of the DCs, such as human capital, social capital and managerial cognition, which emphasize the individual's role and highlight managerial aspect in the development of DCs. Fifth, specific capabilities, but common among companies, allow them to exploit the opportunities offered by the external environment (WANG; AHMED, 2007). These processes are the absorptive 
capacity; innovative capacity; adaptability; the sensing and seizing (HARRELD; O'REILLY III; TUSHMAN, 2007; TEECE, 2007). These five categories consider managerial and organizational processes, strategic processes and individual aspects as development processes of DCs.

Criticism also focuses on the current development of the theory of DCs, in aspects such as the source of competitive advantage. While observing certain evolution in terms of theoretical contributions, there is still not enough empirical support for such arguments (AMBROSINI; BOWMAN, 2009). However it is already noticed a trend of quantitative empirical studies on the DCs, as studies of Drnevich e Kriauciunas (2011) and Molina; Bustinza and Gutiérrez-Gutiérrez (2012). Overall, more refined qualitative studies, such as participant observation, are suggested for understanding the imbrications of DCs in the practice of strategy (GREEN; LARSEN; KAO, 2008). It is also suggested quantitative studies aiming to develop multidimensional metrics for measuring DCs (MENON, 2008). Thus, there are many possibilities for future studies on DCs, both qualitative and quantitative, and new literature reviews. These interlocking shapes are valuable for a well-defined development of the Dynamic Capabilities' Theory.

\section{REFERENCES}

ADNER, R.; HELFAT, C. R. Corporate effects and dynamic managerial capabilities. Strategic Management Journal, v. 24, p. 1011-1025, 2003.

ALSOS, G. et al. The dynamic capability concept and its operationalization. Proceedings of The Babson College Entrepreneurship Research Conference at IE Business School, held on 7 - 9 June in Madrid, Spain, 2007.

ALVAREZ, S. A.; BARNEY, J. B. Resource-Based theory and the entrepreneurial firm. In: Hitt, M.; Ireland, R.; Camp, S.; Donald, S. (Eds.). Strategic entrepreneurship: creating a new mindset. 3. ed. Malden: Blackwell, 2006, p. 89-105.

ARGOTE, LINDA; REN, YUQING. Transactive Memory Systems: A Microfoundation of Dynamic Capabilities. Journal of Management Studies. p. 1-8, 2012.

AMBROSINI, V.; BOWMAN, C. What are dynamic capabilities and are they a useful construct in strategic management? International Journal of Management Reviews, v. 11, n.1, p. 29-49, 2009.

BARNEY, J. B.; ARIKAN, A. M. The resource-based view: origens e implications. In: HITT, M. et al. (Ed.). Strategic entrepreneurship: creating a new mindset. 3. ed. Malden: Blackwell, 2005, p. 124-188.

Is the resource-based "view" a useful perspective for strategic management research? yes. Academy of Management Review, v. 26, n. 1, p.41-56, 2001. 
Firm resources and sustained competitive advantage. Journal of Management, v. 17, p. 99-120, 1991.

BAUMEISTER, R. F.; LEARY, M.R. Writing narrative literature reviews. Review of General Psychology, v. 1, n. 3, p. 311-320, 1997.

BIAZZI, F. Intellectual capital and organizational renewal: building dynamic capabilities through people. Brazilian Administration Review - BAR, v.9, n.spe, p. 38-59, 2012.

BLYLER, M.; COFF, R. W. Dynamic capabilities, social capital, and rent appropriation: ties that split pies. Strategic Management Journal, v. 24, p. 677-686, 2003.

BOWMAN, C.; AMBROSINI, V. How the resource-based and the dynamic capability views of the firm inform corporate-level strategy. British Journal of Management, v.14, p. 289303, 2003.

CAVUSGIL, E.; SEGGIE, S. H.; TALAY, M. B. Dynamic capabilities view: foundations and research agenda. Journal of Marketing Theory and Practice, v. 15, n. 2, p. 159-166, 2007.

CHEN, H.; LEE, P. The driving drivers of dynamic competitive capabilities: a new perspective on competition. European Business Review, v. 21, n, 1, p. 78-91, 2009.

COLLIS, D. J.; MONTGOMERY, C. A. Competing on resources. Harvard Business Review, v. 37, n. 4, p. 118-128, 1995.

COLLIS, D. J. Research note: how valuable are organizational capabilities? Strategic Management Journal, v.15, p. 143-152, 1994.

DELBRIDGE, R.; GRATTON, L.; JOHNSON, G. The Exceptional Manager: Making the Difference. Oxford: Oxford University Press, 2006

DØVING, E.; GOODERHAM, P. N. Dynamic capabilities as antecedents of the scope of related diversification: the case of small firm accountancy practices. Strategic Management Journal, v. 29, p. 841-857, 2008.

DOUGLAS, T. J.; RYMAN, J. A. Understanding competitive advantage in the general hospital industry: evaluating strategic competencies. Strategic Management Journal, v. 24, p. $333-347,2003$.

DRNEVICH, P. L.; KRIAUCIUNAS, A. P. Clarifying The Conditions And Limits Of The Contributions Of Ordinary And Dynamic Capabilities To Relative Firm Performance.

Strategic Management Journal, v. 32, p. 254-279, 2011.

EISENHARDT, K. M.; MARTIN, J. A. Dynamic Capabilities: what are they? Strategic Management Journal, v. 21, p. 1105 - 1122, 2000.

FERDINAND, J. et al. Dynamic capability: tracking the development of a concept. Evolution of business knowledge (EBK Working Paper 2005/09), Swindon, UK, 2005, p. 1-20..

FOSS, N. Resources and strategy: a problems, open issues, and ways ahead. In: FOSS, N. J. (Ed.). Resources firms and strategies - a reader in the resource-based perspective. Oxford: Oxford University Press, p. 345-365, 1997. 
GAVETI, G. Cognition and hierarchy: rethinking the microfoundations of capabilities'development. Organization Science, v. 16, n.6, p. 599 -617, 2005.

GHEMAWAT, P. A estratégia e o cenário dos negócios: texto e casos. Porto Alegre: Bookman, 2000.

GRANT, R M. The resource-based theory of competitive advantage: implications of strategy formulation. California Management Review, v. 33, n. 3, p. 114-135, 1991.

GREEN, K.M; LARSEN, G.; KAO, C. Exploring the relationship between strategic reactiveness and entrepreneurial orientation: the role of structure-style fit. Journal of Business Venturing, v. 23, p. 356-383, 2008.

HARRELD, B.; O'REILLY III, C. A.; TUSHMAN, M. L. Dynamic Capabilities at IBM: driving strategy into action. California Management Review, v. 49, n. 4, p.21-44, 2007.

HELFAT, C. E.; WINTER, S. G. Untangling Dynamic And Operational Capabilities: Strategy For The (N)Ever-Changing World. Strategic Management Journal. v. 32, p. $1243-$ 1250, 2011.

et al. Dynamic Capabilities: understanding strategic change in organizations.

London: Blackwell Publishing, 2007.

.; PETERAF, M. The dynamic resource-based view: capability lifecycles. Strategic Management Journal, v. 24, p. 997-1010, 2003

HENDERSON R. M. Managing innovation in the information age. Harvard Business Review, v. 72, n.1, p.100-106, 1994.

HERRMANN, P. Evolution of strategic management: the need for new dominant designs. International Journal of Management Reviews, v. 7, n. 2, p. 111-130, 2005.

HODGKINSON, G. P.; HEALEY, M. P. Psychological foundations of dynamic capabilities: reflexion and reflection in strategic management. Strategic Management Journal, v. 32, p. 1500-1516, 2011.

HOOPES, D. G.; MADSEN, T. L.; WALKER, G. Guest editors'introduction to the special issue: why is there a Resource-Based View? Toward a theory of competitive heterogeneity. Strategic Management Journal, v. 24, p. 889-902, 2003.

HOSKINSSON, R. et al. Theory and research in strategic management: swings of a pendulum. Journal of Management, v. 25, n. 3, p. 417-456, 1999.

HSU, L.; WANG, C. Clarifying the Effect of Intellectual Capital on Performance: The Mediating Role of Dynamic Capability. British Journal of Management. v. 23, p. 179-205, 2012.

IANSITI M.; CLARK K. B. Integration and dynamic capability: evidence from product development in automobiles and mainframe computers. Industrial and Corporate Change v. 3, n. 3, p. 557-605, 1994. 
LAWSON, B.; SAMSON, D. Developing innovation capability in organizations: a dynamic capabilities approach. International Journal of Innovation Management, v. 5, n. 3, p. 377400, 2001.

LEONARD-BARTON, D. Core capabilities and core rigidities: A paradox in managing new product development. Strategic Management Journal. v. 13, p. 111-125, 1992.

LÓPEZ, S. V. Competitive advantage and strategy formulation: The key role of dynamic capabilities. Management Decision, v. 43, n. 5, p. 661-669, 2005.

MAKADOK, R. Toward a synthesis of the resource-based and dynamic-capability views of rent creation. Strategic Management Journal, v. 24, p. 387 - 401, 2001

LUO, Y. Dynamic capabilities in international expansion. Journal of World Business, v. 35, n. 4 , p. $355-378,2000$.

MARCUS, A. A.; ANDERSON, M. H. A general dynamic capability: does it propagate business and social competencies in the retail food industry? Journal Of Management Studies, p. 19-43, 2006.

MCGUINNESS, T.; MORGAN, R. E. Strategy, dynamic capabilities and complex science: management rhetoric vs. reality. Strategic Change, v. 9, p. 209-220, 2000.

MENON, A.G. Revisiting dynamic capability. IMB Management Review, p. 22-33, 2008.

MOLINA, V. B.; BUSTINZA, O. F.; GUTIÉRREZ-GUTIÉRREZ, L. J. Explaining the Causes and Effects of Dynamic Capabilities Generation: A Multiple-Indicator Multiple-Cause Modeling Approach. British Journal of Management, p. 1-8, 2012.

Montealegre, R. A process model of capability development: lessons from the electronic commerce strategy at bolsa de valores de guayaquil. Organization Science, v. 13, n. 5, p.514-531, 2012.

NELSON, R.; WINTER, S. G. An Evolutionary Theory of Economic Change. Cambridge, MA: Belknap Press of Harvard University Press, 1982.

PENROSE, E. T. Teoria del crescimiento de la empresa. Madrid: Aguilar, 1962.

PISANO, G. In search of dynamic capabilities. In: DOSI, G.; NELSON, R.; WINTER, S. (Eds) The nature and dynamics of organizational capabilities. Oxford: Oxford University Press, p. 129-154, 2000.

PRIEM, R. L. A consume perpective on value creation. Academy of Management Review. v. 32, n.1, p. 219-235, 2007.

RINDOVA, V. P.; KOTHA, S. Continuous "morphing": competing through dynamic capabilities, eorm, and function. Academy of Management Journal. v. 44, n. 6, p. 1263 1280, 2001.

SAPIENZA, H. J. et al. A capabilities perspective on the effects of early internationalization on firm survival and growth. Academy of Management Review, v. 31, n. 4, p. 914-933, 2006. 
SCHREYÖGG, G.; KLIESCH-EBERL, M. How dynamic can organizational capabilities be? towards a dual-process model of capability dynamization. Strategic Management Journal, v. 28, p. 913-933, 2007.

SCHROEDER, R. G.; BATES, K. A.; JUNTTILA, M. A. A resource-basead view of manufacturing strategy and the relationship to manfacturing performance. Strategic Management Journal, v. 23, p. 105- 117, 2002.

SIRMON, D. G.; HITT, M. A.; IRELAND, R. D. Managing firm resources in dynamic environments to create value: looking inside the black box. Academy of Management Review, v. 32 n.1, p. 273- 292, 2007.

TEECE, D. J. Dynamic Capabilities: Routines versus Entrepreneurial Action. Journal of Management Studies, p. 1-8. 2012.

Explicating dynamic capabilities: the nature and microfoundations of (sustainable) enterprise performance. Strategic Management Journal, v. 28, n. 7, p. 1319-1350, 2007. 1986. Profiting from technological innovation. Research Policy, v.15, n.6, p. 285-305,

TEECE, D. J.; PISANO, G. The dynamic capabilities of firms: an introduction. Industrial and Corporate Change, v. 1, n. 3, p. 537-556, 1994.

TEECE, D. J.; PISANO, G.; SHUEN, A. Dynamic capabilities and strategic management. In: FOSS, N. J. (Ed.). Resources firms and strategies - a reader in the resource-based perspective. Oxford: Oxford University Press, p. 268-285, 1997.

ZAHRA, S. A.; SAPIENZA, H. J.; DAVIDSSON, P. Entrepreneurship and dynamic capabilities: a review, model and research agenda. Journal of Management Studies, v. 43, n. 4, p. 917-955, 2006.

TORRACO, R.J. Writing integrative literature reviews: guidelines and examples. Human Resource Development Review, v. 4, n. 3, p. 356-367, 2005.

ZOLLO, M.; WINTER, S. G. Deliberate Learning and the Evolution of Dynamic Capabilities. Organization Science, v. 13, n. 3, p. 339-351, 2002.

ZOTT, C. Dynamic capabilities and the emergence of intraindustry differential firm performance: insights from a simulation study. Strategic Management Journal, v. 24, p. $97-$ $125,2003$.

WANG, C. L.; AHMED, P. K. Dynamic capabilities: A review and research agenda. International Journal of Management Reviews, v. 9, n.1, p. 31-51 31, 2007.

WILKENS, U.; MENZEL, D.; PAWLOWSKY, P. Inside the Black-box: Analysing the Generation of Core Competencies and Dynamic Capabilities by Exploring Collective Minds. An Organizational Learning Perspective. Management Revue, v. 15, n. 1, p. 8-27, 2004.

WINTER, S. G. Understanding dynamic capabilities. Strategic Management Journal. v. 24, p. 991-995, 2003. 
WITCHER, B. J.; CHAU, V. S.; HARDING, P. Dynamic capabilities: top executive audits and hoshin kanri at Nissan South Africa. International Journal of Operations \&

Production Management, v. 28, n. 6, p. 540-561, 2008.

\section{The authors thank CNPQ for financial support.}

\section{APPENDIX A - DEFINITIONS AND EMPHASES OF DCs}

\begin{tabular}{|c|c|c|}
\hline Authors & Definition of DC & Emphasis \\
\hline $\begin{array}{l}\text { Teece, Pisano } \\
\text { and Shuen, } \\
\quad(1997)\end{array}$ & $\begin{array}{l}\text { We define dynamic capabilities as the company's ability to integrate, build and } \\
\text { reconfigure internal and external competencies to address rapidly changing } \\
\text { environments. Dynamic capabilities thus reflect an organization's ability to } \\
\text { achieve new and innovative forms of competitive advantage, depending on the } \\
\text { path and positioning in the market (p. 516). }\end{array}$ & $\begin{array}{l}\text { Organizational } \\
\text { skills }\end{array}$ \\
\hline $\begin{array}{l}\text { Eisenhardt and } \\
\text { Martin (2000) }\end{array}$ & $\begin{array}{l}\text { Dynamic capabilities thus are the organizational and strategic routines, in which } \\
\text { organizations achieve new resource configurations as soon as markets emerge, } \\
\text { collide, split, evolve and die (p.1107). }\end{array}$ & $\begin{array}{l}\text { Organizational } \\
\text { routines }\end{array}$ \\
\hline Luo (2000) & $\begin{array}{l}\text { Dynamic capability can be defined as the ability of the multinational } \\
\text { organization to create, use and update resources organizationally intertwined } \\
\text { and generate returns based on resources in the search for sustainable } \\
\text { competitive advantages in the global market. Dynamic capabilities require the } \\
\text { ability to extract economic benefits from current resources and develop new } \\
\text { capabilities (p. 355) }\end{array}$ & $\begin{array}{l}\text { Organizational } \\
\text { capabilities and } \\
\text { skills }\end{array}$ \\
\hline $\begin{array}{c}\text { Zollo and } \\
\text { Winter (2002) }\end{array}$ & $\begin{array}{l}\text { The dynamic capability is a collective activity's learned and stable pattern from } \\
\text { which the organization systematically generates and modifies its operating } \\
\text { routines in pursuit of greater efficiency (p. } 340 \text { ). }\end{array}$ & $\begin{array}{l}\text { Patterns and } \\
\text { processes of } \\
\text { learning }\end{array}$ \\
\hline $\begin{array}{l}\text { Bowman and } \\
\text { Ambrosini } \\
\text { (2003) }\end{array}$ & $\begin{array}{l}\text { The dynamic capability approach focuses attention on the organization's ability } \\
\text { to renew its resources according to changes in their environment. [...] The } \\
\text { dynamic capabilities' view (DCV) focuses on the ability of an organization } \\
\text { facing a rapidly changing environment have to create new resources, to renew } \\
\text { or change their mix of resources. (p. 292). }\end{array}$ & $\begin{array}{l}\text { Organizational } \\
\text { skills }\end{array}$ \\
\hline Zott (2003) & $\begin{array}{l}\text { More specifically, dynamic capabilities are embedded in organizational } \\
\text { processes and organizational routines that guide the evolution of resources and } \\
\text { organization's operational routines (Helfat \& Raubitschek 2000: 975; Nelson \& } \\
\text { Winter, 1982; Zollo and Winter, 2002). (p. 98) More specifically, dynamic } \\
\text { capabilities are incorporated into the routine of organizational processes that } \\
\text { guide the evolution of resource's configuration organization routines and } \\
\text { operational routines (Helfat \& Raubitschek, 2000: 975; Nelson \& Winter, 1982; } \\
\text { Zollo \& Winter, 2002). (p. 98) }\end{array}$ & $\begin{array}{l}\text { Processes and } \\
\text { organizational } \\
\text { routines }\end{array}$ \\
\hline $\begin{array}{l}\text { Helfat and } \\
\text { Peteraf }(2003)\end{array}$ & $\begin{array}{l}\text { The dynamic capabilities build, integrate or reconfigure operational capabilities. } \\
\text { The dynamic capabilities do not directly affect organizational performance, but } \\
\text { indirectly contribute to organizational performance through its effect on the } \\
\text { operational capabilities (p. 997) }\end{array}$ & $\begin{array}{l}\text { Organizational } \\
\text { processes }\end{array}$ \\
\hline $\begin{array}{l}\text { Marcus \& } \\
\text { Anderson } \\
(2006)\end{array}$ & $\begin{array}{l}\text { A general dynamic capability is the ability to renew, expand and adapt skills } \\
\text { over time (Teece, Pisano, \& Shuen, 1992, p. 18; Tripsas, 1997; Winter, 2003) } \\
\text { (p. 19) }\end{array}$ & $\begin{array}{l}\text { Organizational } \\
\text { skills }\end{array}$ \\
\hline $\begin{array}{l}\text { Zahra, } \\
\text { Sapienza and } \\
\text { Davidson } \\
(2006)\end{array}$ & $\begin{array}{l}{[\ldots] \text { dynamic capabilities, which we define as the ability to reconfigure }} \\
\text { resources and routines of the organization so planned and considered } \\
\text { appropriate by its principal decision maker (s) (p. } 918) \text {. }\end{array}$ & $\begin{array}{l}\text { Organizational } \\
\text { skills }\end{array}$ \\
\hline $\begin{array}{l}\text { Helfat et al. } \\
\qquad(2007)\end{array}$ & $\begin{array}{l}\text { Dynamic capability is the ability of an organization intentionally create, expand } \\
\text { or modify its resources base (p. 4). }\end{array}$ & $\begin{array}{l}\text { Organizational } \\
\text { capacity }\end{array}$ \\
\hline
\end{tabular}




\begin{tabular}{|c|l|c|}
\hline $\begin{array}{c}\text { Wang and } \\
\text { Ahmed } \\
(2007)\end{array}$ & $\begin{array}{l}\text { We define dynamic capabilities as an organization behavioral orientation } \\
\text { constantly to integrate, reconfigure, renew and recreate its resources and } \\
\text { capabilities, and most importantly, upgrade and rebuild its core capabilities in } \\
\text { response to changes in the environment to achieve and sustain competitive } \\
\text { advantage. For this setting, first it is argued that dynamic capabilities are not } \\
\text { just processes, but embedded in processes. (p. 35) }\end{array}$ & $\begin{array}{c}\text { Set of } \\
\text { organizational } \\
\text { processes }\end{array}$ \\
\hline $\begin{array}{c}\text { Teece (2007) } \\
\text { manamic capabilities, moreover, relate to high-level activities pointing to } \\
\text { and combine and reconfigure specialized co-specialized assets and to meet the } \\
\text { needs of customers and to support and extend evolutionary fitness, thus } \\
\text { developing long-term value for investors (p. 1344). }\end{array}$ & $\begin{array}{c}\text { Organizational } \\
\text { management } \\
\text { skill }\end{array}$ \\
$\begin{array}{c}\text { Savusgil, } \\
\text { Talay (2007) }\end{array}$ & $\begin{array}{l}\text { Specific organizational processes by which managers alter their resource base } \\
\text { (p. 162). }\end{array}$ & $\begin{array}{c}\text { Organizational } \\
\text { processes }\end{array}$ \\
\hline $\begin{array}{c}\text { Døving and } \\
\text { Gooderham } \\
(2008)\end{array}$ & $\begin{array}{l}\text { Our view is that dynamic capabilities are best conceived as durable routines, } \\
\text { systems and processes that are visible, known and are managerially intended as } \\
\text { a means to achieve new resource configurations (p. 845). }\end{array}$ & $\begin{array}{c}\text { Routines, } \\
\text { processes and } \\
\text { organizational } \\
\text { systems }\end{array}$ \\
\hline $\begin{array}{c}\text { Ambrosini and } \\
\text { Bowman } \\
\text { (2009) }\end{array}$ & $\begin{array}{l}\text { The dynamic capacity is not a capacity towards RBV, a dynamic capability is } \\
\text { not a resource. The dynamic capability is a process that has an impact on the } \\
\text { resources (p. 34) }\end{array}$ & $\begin{array}{c}\text { Organizational } \\
\text { processes }\end{array}$ \\
\hline
\end{tabular}

\section{NOTES}

${ }^{\mathrm{i}}$ Routines are patterns of interactions that represent successful solutions to specific problems. These patterns of interactions reside on group behavior, although certain subroutines may reside on individual behavior (TEECE; PISANO, 1994, p. 545). 